\title{
Communication as Sociocultural Meaning Exchange: The Example of Richard Wright's Black Boy
}

\author{
Iyabode Omolara Akewo Daniel \\ Department of English \\ School of Arts \& Social Sciences \\ National Open University of Nigeria, Lagos \\ E-mail: akewoauthe@gmail.com; idaniel@noun.edu.ng
}

Received: 05-06-2013

doi:10.7575/aiac.ijalel.v.2n.5p.173
Accepted: 06-07-2013

Published: 01-09-2013

URL: http://dx.doi.org/10.7575/aiac.ijalel.v.2n.5p.173

\begin{abstract}
Communication is expected to result in meaning exchange. However, when definite meanings could not be established in a communication exchange, an odd situation usually results. Such situations are observed to actually go beyond syntactic and logical misnomer in the communication process. This paper thus examines the semantic oddities in Richard Wright's Black Boy. It made use of the linkage points of such linguistic approaches like pragmatics, semiotics, presupposition and truth-condition semantics to do a semantic analysis of the novel. It found that sociological factors have a great deal of influence on the odd way of interpreting utterances/communication signals in the text. The paper therefore advocates that there is the need to incorporate co-text sociological elements as being of relevance to meaning analysis.
\end{abstract}

Keywords: Communication, Meaning exchange, Presupposition, Semantic oddities, Truth conditional semantics

\section{Introduction}

A communicative act is one which involves exchange of meaning. The meaning may be social, psychological, logical or even cultural. In defining communication, Lyons (1977: 32-33) differentiates between communicative and informative signals. Communicative signal, to him, is the intention of the sender to make the receiver aware of something. Informative signal, on the other hand, involves the receiver becoming aware of something which s/he was not previously aware of "regardless of the intention of sender". Following from this, a signal is communicative, depending on the sender's choice or selection while the signal is informative only if it tells the receiver something new. This, to him, is the communicative process. This agrees with Obe (2008) position.

Language as an instrument of communication is a semiotic system. Semiotic system, which is defined by Lyons (1977) as "systems of signalling-behaviour" (56), goes beyond mere signalling of verbal systems. It also involves the nonverbal signs (Scollon \& Scollon, 2003). Semiotics accounts for signalling social behaviours, attitudes, etc. This aspect of semiotics is described by Halliday (1978) as 'social semiotics'. To him, language functions in a social environment as a signalling system. It depends on context however for it to be meaningful. This brings in the idea of pragmatics.

Pragmatics has been described by different scholars in different ways. To Morris (1938:6) cited in Lyons (1977:115) “it is the relation of signs to interpreter". In revising this definition in 1946, he states that "pragmatics is that portion of semiotics which deals with the origin, uses and effects of signals within the behaviour in which they occur..." (218-19)

Carnap (1942:9) sees pragmatics as an investigation into natural language in which explicit reference is to the speaker cum users of the language. Smith (1966:4-5) on his part sees it as the study of signs and how they are related to people. In summarizing all these definitions, Lyons (1977:117) concludes these scholars discussion on pragmatics by stating that the analysis of meaning in the natural language involves pragmatic consideration. Levinson (1983) asserts that pragmatics tries to account for the contextual factors constraining the particular linguistic usage. As such, pragmatics explains the fact that a linguistic psychological base goes beyond processing to account for the deliberate use of language to particular ends and how these deliberate manipulations are realised in communication. Nonetheless, Hopper and Traugott (2003) opine that a "linguistic theory should eventually provide an integrated account of semantics and pragmatics" (76). This is because the participants and the meaning they make altogether determine the communicative effectiveness of the linguistic choices.

This paper therefore assumes the position that in the course of analysing meaning, the communication event, which involves exchange of meaning between sender(s) and receiver(s), cannot but take cognizance of the social signallingsystem and its implication for the cultural context. Meaning construal, the paper also opines, is dependent on the people that make up the social set up. In pursuance of this position, the paper therefore adopts the interrelationship that is observed in these areas of the science of meaning previously referred to in order to do a semantic analysis of Black Boy by Richard Wright, an American writer. It specifically examines the semantic oddities observed in the book, among the 
characters interrelationships and the significance of the book as a whole to the racial situation that was prevalent in the America of the early part of the 20th century, and possibly the present time.

Not ignoring the logical aspect of meaning, the paper tries to show that truth value and face value are sometimes made to seem the same by the characters. Truth value here follows the definition of Tarski's model of truth conditional semantics (cf. Kempson, 1977; Daniel, 2003). Truth value in the text seems to have been replaced by face value.

Face value is being used here to describe a situation in which the truth value of utterances is governed, not by the conditions that make for the utterances to be true (as proposed in the Tarskian truth conditional semantics), but social values that make participants deny truth and put instead social constructs to determine the truth of an utterance. It does not seem to matter what is uttered so long as it fits into the expected social status quo. A false value is placed on truths while truth values are placed on falsehoods because they fit into the expectation of the participants. This set up also appears to indicate a sort of power structure in the society. This entitlement to decide what is true or false rests in the group that has "appropriated power" (Shuman, 1992). This situation is described by Brown and Gilman (1972:257) as "asymmetrical" power relations. Essentially, this entitlement to decide what is true and what is not is usually rested in political power as determinant of communication content as argued by van Dijk (1995) and Fairclough (2001). Truth is thus determined by who decide what is truth. This can be seen exemplified in the poems of Ogundipe-Leslie and Yeibo as extensively analysed in Daniel (2008).

\section{Black Boy and Power Relations}

To a large extent, Black Boy is the story of imbalance of political, social and psychological power sharing within the American society of the early $20^{\text {th }}$ century. The African-Americans are the ones subsumed under the white man. The white man ruled the Negro and has the right to call them whatever he likes $(180,217)$, do to them what he likes $(63$, 200). All these informed the prevalent social relations and created a psychological context from which the book sprang. The power structure is bent on destroying the humanity of the Negro. It therefore continued to kill them physically or through a more subtle way of confining them to a part of the society and making them feel less than human at every possible occasion $(201,207)$.

Through the demoralizing larger social milieu, the asymmetrical power structure found its way into the midst of the Black community, which seems to inform the attitude of many of the adults to the children. This is apparently demonstrated by the scene involving Richard, his brother and their father (16-18), the reaction of Uncle Tom to his seemingly innocent reply to his (Richard's) question (172-3). This misunderstanding of Richard's remark and Uncle Tom's subsequent reaction may be informed by the power relations than any intentional use of language to derogate him on Richard's part. This, the author makes clear on page 175 when he says: "I didn't mean to hurt your feelings..."

\section{Semantic Oddities in Richard Wright's Black Boy}

This paper posits that the use of language and the consequences that ensued in Black Boy are largely informed by the above stated relations. If communication is the exchange of meanings, semiotics, signification of meanings and pragmatics, how these signs signifying meanings are related to people using the language (cf. Levinson, 1983), Black Boy has a lot of semantic oddities informed by the power structure and social relations.

Taking cognizance of the verbal/non-verbal dichotomy of communication, the paper tries to investigate the whole system of signalling behaviour beyond mere vocal/verbal level of signalling. Importance of the context cannot be overemphasised in this study; it is the total structure which informs the odd ways meanings are exchanged in the text.

Semantic oddities is here seen as the way language is used to exchange meanings that are superfluous and determined essentially by the social relations of participants rather than the logical structure of the utterance itself.

\subsection{Intentionless Meaning}

"Kill that damn thing!" my father exploded... He went inside, grumbling. I resented his shouting and it irked me that I could never make him feel my resentment. How could I hit back at him? Oh yes... He said to kill the kitten, but my hate of him urged me toward a literal acceptance of his word. "He said for us to kill the kitten," I told my brother. "He didn't mean it," my brother said. "He did, and I'm going to kim 'im" ... "He didn't mean for you to kill 'im," my brother said. "Then why did he tell me to do it?" I demanded...

(After killing the kitten and the father being made aware of the fact.)

"I told you to drive it away," he said (the father) "You told me to kill 'im," I countered positively. I had my first triumph over my father. I had made him believe that I had really taken his words literally. He could not punish me now without risking his authority...

This extract centres on a seeming misunderstanding of the actual intention of the father and the supposed information conveyed to the son. Communication, as we have seen above, conveys the sender's intention and through informative signal, the receiver gets the new information (cf. Obe, 2008). But here, the construct given by the father states logically 
one truth "kill” while the son got the message "don't kill". However, the son decided to "to kill" because of his resentment of the asymmetric power relation existing between them.

This reveals a startling fact that the truth-conditional semantics cannot handle a situation where an actual communication took place but due to pragmatic social relations, it is scuttled. Neither can the speech act theory be able to fully account for this extract in that the father finally believes the boy to have misunderstood his intention. The intentionless meaning of the father made him to withdraw from punishing the boy for claiming to have misunderstood him (the father) in order to protect his 'authority'. Even though the brother insisted that Richard should have understood what their father meant and their mother later beat him (Richard) for lying by claiming to have misunderstood his father, it is obvious that the father actually accepted the boy's claim.

Du Bois (1992) on functions of intentionless meaning states that one of them is the possibility of the relationships of the persons involved having to determine meaning and responsibilities. This is usually based on these factors rather than just the facts themselves, except they have been socially "legitimated" (63).

This might have informed the triumph that Richard feels he has attained in making the father believe he has taken him (the father) literally and why the father could not risk punishing him by assuming the boy had actually misunderstood his intention. The communication process has been determined by the power exchange. Responsibility for the decision that informed the act had been passed to the older man even though he might not have actually intended for the act to take place.

\subsection{Presupposition in Fraternal Exchanges}

Presupposition is the assumed knowledge between interlocutors. Presupposition is that part of the utterance which is familiar (Leech, 1974) to the interlocutors. Brown and Yule (1983:29) identify pragmatic presupposition as "assumptions the speaker makes about what the hearer is likely to accept without challenge" following Givon (1977:50) and Stalkner (1978: 321) who opine that it is the "assumed "common ground' of participants" in the conversation. A situation of an actual communication breakdown is lacking but there is the absence of ideal communication. This is what Harder and Kock (1976:14) describe as presupposition failure.

Looking at these different definitions of presupposition, one sees that presupposition is highly pragmatic in that it has to do with the participants more than merely the language. The extent of which they share the assumptions makes for the smooth, uninterrupted flow of the communication. Where these assumptions are not substantiated, there is the problem of total agreement between the participants.

In chapter three of Black Boy, the exchanges between the boys hinged on the knowledge they have of their world. Their world is that of "black-eyed peas" and the fact that it causes one to "smell up the air" (89). This world also include the use of nigger, which is supposed to "prove the tough fibre of our feelings" (88), without its derogatory overtones. It has to do with the extended discussion of the oppressive whites and the injustices associated with their relations with the Blacks as well as the war, the Blacks participation, and the poison gas (hydrogen bomb) and the fear the whites have for the Blacks.

This world also has to do with the constant threat of physical assault on Blacks and the Blacks' displeasure, which informs their wanting to retaliate, and flee, going North and escaping the suffocating white domination. But the realm of abandoning reality of the shared experiences to go into the realm of speculation strained the meanings that were so easily exchanged previously:

"Listen, you know them building up north is as tall as they say this is?" Leaping by association to something concrete and trying to make belief real.

“They say they gotta building in New York forty stories high!” A thing too incredible for belief.

"Man, I'd be scareda them buildings!" Ready to abandon the now suppressed idea of flight.

"You know, they say that them buildings sway and rock in the wind." Stating a miracle.

"Naw, nigger!" Utter astonishment and rejection.

"Yeah, they say they do." Insisting upon the miracle.

"You recknon that could be?" Questioning hope.

"Hell, naw! If building swayed and rocked in the wind, hell, it'd fall! Any fools knows that! Don't let people make fool outta you, telling you them things?" Moving body agitatedly, stomping feet impatiently and scurrying back to reality.

"Man what makes white folks so mean?" Returning to grapple with the old problem.

"Whenever I see one I spit." Emotional rejection of whites.

At this point, it is obvious that the meaning exchange has become strained in that they have gone away from reality, that is, what is familiar to their youth world. This is what led to make beliefs and uncertainties about the interpretation to be put on the claim that buildings sway, as if they were drunks. This is finally authoritatively put to rest by the revelation that "Any fool" knows that "if a building swayed and rocked in the wind, hell, it'd fall." 
The fact that the supposed assumption of the participant claiming that buildings sway is challenged has led to presupposition failure on his part. However, their ability to return to 'safe reality' shows that the communication has not really broken down but that it is no longer 'straight forward' (Harder \& Kock, 1976) at the point of interruption. This proves to be mere noise in the communication channel. They then return to what the author, in giving semantic clues to the interlocutors' statements, describes as 'safe reality'.

Another important factor that led to presupposition failure is 'they say', which imputes the statements to another source. This already makes the claims questionable when they are compared to their former and subsequent exchanges. Whenever such third party (outside the group) is referred to as the source of the information, it carries a responsibility weight as in "My mama says..." (91) unlike the faceless proform 'they', which charges no one with the responsibility of being the bearer of the news. Such persons also seem to exist outside of the interlocutors' small world. The fraternal relationship however seems to make it easier for them to interpret the utterances at their level.

\subsection{False Values as Truth Values}

Truth condition semantics of Tarski proposes a situation where an utterance is true if and only if the conditions surrounding it are favourable to its truth (Kempson, 1977: 23-43). Austin's Speech Act semantics sees utterances as being meaningful, depending on what they are employed to do (Kempson, 1977: 50-55). Pragmatics, to Smith (1966) in Lyons (1977:116), is the relationship between the signs and the user as what determines meaning. All these concepts tend to try to see meaning as a thing that exists by itself and not informed by the context.

In taking a closer look at the utterances and exchanges involving the whites and the Blacks, Black Boy, it appears that the social milieu strictly determines the construct put on utterances rather than their nature. The context of the political reality seems to inform the meaning of utterances. A few of the scenes below exemplify the point being made here.

On page 217, the white watchman feels he has the right to slap the Negro girl on the buttocks with nobody to challenge this act. At Richard's reaction of anger, which to the man white watchman conveys the meaning that he (Richard) is challenging the right of the white man to touch a Negro girl when he pleases, he got the logical reply, "Yes, sir" to his question "Don't you like it, nigger?" Even though, psychologically, Richard objected to the man's action, socially, he has to agree with it. Anything short of this spells his doom.

Another scenario is on page 209, the encounter between Richard, Pease and Reynolds. Reynolds and Pease actually know that Reynolds made up the story about Richard calling 'Pease' without adding 'Mr'. The very readiness with which they went prepared to brutalise him warned Richard of the fact that he is in a tight corner...

"Now be careful, nigger" snarled Reynolds, baring his teeth. "I heard you call 'im Pease. And if you say you didn't, you're calling me a liar, see?” He waved the bar threateningly.

This very utterance reveals the options left to the young man. His accepting or denouncing the accusation would get him into trouble. But quickly, he comes to the realisation that he is being covertly asked to leave his job. It does not matter whether calling 'Pease' without adding ' $\mathrm{Mr}$ ' is true or not; what really matters is that he must leave the job. Reynolds therefore socially becomes the person who is true and the young boy must be false - by the virtue of their social status, the power balance.

Such examples abound in the book. The uninhibited molestation of the Black lady by the white bosses of Richard in chapter nine, page 198; the turning around of the policeman to accuse the lady of being drunk after she had been abused by the white man and his son; the hitting of Richard with a bottle on the face by the white man in the car on page 200 for not adding 'sir' to his 'Oh no!'; the use of lies as truths by the whites to elicit fun from Richard and Harrison in boxing (250-260), the expectation of the Blacks to feel good about bad things (280). All these things have actually helped to create the expected construal on social meanings.

Richard had to tell many lies, otherwise he might never have been able to leave for the North or probably he might have gotten killed. When accused of planning to change once he gets up North, he had to lie that he would not (280). It then seems obvious that semantics needs to go beyond mere logical or philosophical interpretation of meaning. Even linguistic values may not be sufficient to interpret meaning (cf. Daniel, 2012). As was discovered in the story of Black Boy, meaning is more social than merely logical. It is true only as far as it fits into the status quo. False propositions are accepted as true on the basis of the social power play as it was in the cultural milieu of the southern States of America in the book.

\section{Conclusion}

This paper has tried to show that meaning is important in communication. It also attempts to show that meaning is encapsulated in the semiotic structure of the society in which the communication event is occurring. Moreover, the paper sees meaning as being more relevant to the people who are engaging in the communication process and their attitudes.

Having said this much, the paper opines that as far as Wright's Black Boy is concerned, semantic oddities are prevalent. This, it finds, is due to the social relations existing in the society portrayed in the book. Truths of utterances are determined, not by their propositional or factual contents, but by the social forces governing the society. As Richard Wright himself observes: 
I did not want to lie, yet I had to lie to conceal what I felt. A white censor was standing over me and, like dreams forming a curtain for the safety of sleep, so did my lies form a screen of safety for my living moments (280).

A problem then arises on how meanings can be exchanged and accepted as truth if lies (i.e. falsehoods) have become a necessary part of the inter-relationships. This paper thus submits that the semantic oddities can be made 'normal' only by the normalization of the societal oddity, which informed the book in the first place. Saying what is meant and not what is expected to be said are two different things. Has America of today changed from Wright's America? As much as the apparently astounding election of President Barack Obama (the first African-American mixed blood US president) in 2008 and re-election in 2012 will want to make us believe so, the subsequent and persistent actions of $\mathrm{Ku}$ Klux Klan and the Tea Party make the world to wonder. The shmoopers also seem to feel the same (cf. www.shmoop.com/black-boy/).

\section{References}

Brown, G., \& Yule, G. (1983). Discourse analysis. Cambridge: Cambridge University Press.

Brown, R., \& Gilman, A. (1972). Pronouns of power and solidarity. Language and social structure. Giglioli, P. P. (ed.) London: Penguin.

Daniel, I. O. (2003). Gender equality: A semantic analysis of Ola Rotimi's Our husband has gone mad again. Journal of Nigerian, foreign and English language and literatures, 1(3), 269-276.

Daniel, I. O. (2008). Barren rivers and flowery women: Metaphors of domination and subjugation in select poems of Ebi Yeibo and Molara Ogundipe-Leslie. The journal of pan African studies, 2(5), 99-110.

Daniel, I. O. (2012). Transliteration as communication weapon in Nigerian English. Journal of Nigerian English studies association. 15 (2), 98-117

Du Bois, J. W. (1992). Meaning without intention: Lesson from divination. Responsibility and evidence in oral discourse. Hill, J. H., \& Irvine, J. T. (eds.) Cambridge: Cambridge University Press.

Fairclough, N. (2001). The dialectics of discourse. Textus XIV, 2001, 231-242. Retrieved August 8, 2006 from

http://www.geogr.ku.dk/courses/phd/glob-loc/papers/phdfairclough2.pdf.

Halliday, M. A. K. (1978). Language as a social semiotic: The social interpretation of meaning. London: Edward Arnold

Harder, P. \& Kock, C. (1976). The theory of presupposition failure. Copenhagen: Akademisk Forlag.

Hopper, P. J. \& Traugott, E. C. (2003). Grammaticalization. 2nd edn. Cambridge: Cambridge University Press.

Kempson, R. M. (1977). Semantic theory. Cambridge: Cambridge University Press.

Leech, G. M. (1974). Semantics. London: Penguin.

Leech, G., \& Thomas, J. (1990). Language, meaning and context: Pragmatics.

Encyclopaedia of language, (pp. 173-206.). N. E. Collinge. Ed. London and New York: Routledge.

Levinson, S. C. (1983). Pragmatics. Cambridge: Cambridge University Press.

Lyons, J. (1977). Semantics I. Cambridge: Cambridge University Press.

Obe, J. (2008). Introduction to mass communication. Lagos: National Open University of Nigeria.

Scollon, R. \& Scollon, S. W. (2003). Discourse in places: Language in the material world. London and New York: Routledge.

Shmoopers. A. (2013). Black boy - In a nutshell. Retrieved May 31, 2013 from www.shmoop.com/black-boy/.

Shuman, A. (1992). Get outa my face: Entitlement and authoritative discourse. Responsibility and evidence in oral discourse. Hill, J. H. \& Irvine, J. T. (eds.) Cambridge: Cambridge University Press.

Van Dijk, T. (1995). The mass media: Discourses of domination or diversity. Discourse in society. Retrieved February 18, 2008 from http://www.discourse.org/OldArticles/Themediatoday.pdf.

Wright, R. (1937). Black boy. New York: Harper and Row Publishers. 